\title{
REINVESTIGATION AND APPLICATION OF OLIVINE-QUARTZ-ORTHOPYROXENE BAROMETRY
}

\author{
STEVEN R. BOHLEN * and ERIC J. ESSENE \\ Department of Geology and Mineralogy, University of Michigan, Ann Arbor, MI 48104 (U.S.A.)
}

\section{A.L. BOETTCHER}

Institute of Geophysics and Planetary Physics and Department of Earth and Space Sciences, University of California at Los Angeles, Los Angeles, CA 90024 (U.S.A.)

Received March 19, 1979

Revised version received October 29, 1979

\begin{abstract}
Experiments in a piston-cylinder apparatus have been carried out at $700-1050^{\circ} \mathrm{C}, 10-16 \mathrm{kbar}$ to determine the stability of ferrosilite $\left(\mathrm{FeSiO}_{3}\right)$ relative to fayalite + quartz. Reaction reversals within 0.1 -kbar intervals locate the equilibrium at $10.5,11.0,11.5,12.0,12.6,13.3,14.1$ and $14.8 \mathrm{kbar}$ at $700,750,800,850,900,950,1000$, and $1050^{\circ} \mathrm{C}$, respectively, reflecting the intercept with the $\alpha-\beta$ quartz transition at about $880^{\circ} \mathrm{C}$. The tight reversals severely constrain the reaction slope, providing a basis for limited extrapolation and calculations. However, the lack of accurate activity and cation-distribution data for orthopyroxene and olivine generates substantial uncertainties when considering the effects of large proportions of additional components such as $\mathrm{MgO}$. Experiments and calculations indicate that additional components dramatically extend the pyroxene stability field and that pressures that have been inferred from ferrosilite-rich pyroxenes in natural assemblages are 1-3 kbar too high.
\end{abstract}

\section{Introduction}

In the pioneering experiments on the $\mathrm{MgO}-\mathrm{FeO}$ $\mathrm{SiO}_{2}$ system, Bowen and Schairer [2] have shown that fayalite-quartz is the stable assemblage relative to the compositionally equivalent iron pyroxene, $\mathrm{FeSiO}_{3}$, at atmospheric pressure. Other workers [35] have shown that $\mathrm{FeSiO}_{3}$ is a stable phase at high pressures. More recently Smith [1] and Wood and Strens [6] have attempted to experimentally calibrate parts of the $\mathrm{Fe}_{2} \mathrm{SiO}_{4}-\mathrm{SiO}_{2}$ and $\mathrm{Fe}_{2} \mathrm{SiO}_{4}-\mathrm{Mg}_{2} \mathrm{SiO}_{4}-$ $\mathrm{SiO}_{2}$ systems. Smith [1] has determined the pres-

\footnotetext{
* Present address: Institute of Geophysics and Planetary Physics, University of California at Los Angeles, Los Angeles, CA 90024, U.S.A.
}

\footnotetext{
Institute of Geophysics and Planetary Physics Publication No. 1877. Mineralogical Laboratory, University of Michigan, Contribution No. 347.
}

sure-temperature dependence of the reaction:

$$
2 \mathrm{FeSiO}_{3} \rightleftharpoons \mathrm{Fe}_{2} \mathrm{SiO}_{4}+\mathrm{SiO}_{2}
$$

and has also experimentally evaluated the effect of $\mathrm{MgO}$ on the orthopyroxene-olivine-quartz system at $900^{\circ} \mathrm{C}$. Wood and Strens [6] experimentally investigated the $\mathrm{Fe}_{2} \mathrm{SiO}_{4}-\mathrm{Mg}_{2} \mathrm{SiO}_{4}-\mathrm{SiO}_{2}$ system with up to 40 mole $\% \mathrm{Mg}_{2} \mathrm{SiO}_{4}$ at $1100^{\circ} \mathrm{C}$ and $1250^{\circ} \mathrm{C}$ and have thermodynamically modeled the system for all relevant $P-T$. These investigators have emphasized the potential of the system for use as a geobarometer, and within the past few years a number of workers [7-9] have applied this barometer to natural Fe-rich orthopyroxene and/or olivine-quartz assemblages. However, because of uncertainties in pressure corrections in piston-cylinder apparatus and a lack of tight reversals constraining reaction slopes, there may be significant error in estimation of metamorphic pressures using this system. Additionally, the experi- 
mental data and extrapolations of the data in the $\mathrm{Fe}_{2} \mathrm{SiO}_{4}-\mathrm{Mg}_{2} \mathrm{SiO}_{4}-\mathrm{SiO}_{2}$ system have been applied to natural assemblages without proper regard for substantial amounts of additional components in orthopyroxene, ty pically up to $1.5 \mathrm{wt} . \% \mathrm{CaO}, 4 \mathrm{wt} . \% \mathrm{MnO}$, and $1 \mathrm{wt} . \% \mathrm{Al}_{2} \mathrm{O}_{3}$. Data from natural orthopyroxeneolivine-quartz assemblages indicate that $\mathrm{Ca}$ and $\mathrm{Al}$ are very strongly partitioned into the pyroxene while $\mathrm{Mn}$ shows slight preference for pyroxene. Qualitatively the effect of these impurities is to extend the stability of pyroxene. However, with the exception of $\mathrm{MnO}$ [11] (see following paper), the magnitude of the necessary pressure correction is uncertain. In applying the barometer, this effect has generally been ignored. Ferrosilite component in orthopyroxene has usually been calculated as $\mathrm{Fe}^{2+} /\left(\mathrm{Fe}^{2+}+\mathrm{Mg}\right)$, and an equilibrium pressure inferred on that basis. However, both field data and thermodynamic calculations suggest that the magnitude of the shift in orthopyroxene-olivine-quartz equilibria, because of impurities such as $\mathrm{Ca}, \mathrm{Mn}, \mathrm{Ti}, \mathrm{Al}^{\mathrm{VI}}, \mathrm{Al}^{\mathrm{IV}}, \mathrm{Fe}^{3+}$, etc., is substantial and must be considered. In the Adirondack Highlands, for instance, Jaffe et al. [9] have inferred minimum pressures of 9-11 kbar based on the occurrence of ferrosilite $\left(\mathrm{Fs}_{95}{ }^{*}\right)$ for metamorphic $T=$ $780 \pm 50^{\circ} \mathrm{C}[12,13]$. However, any pressure estimates greater than $9.7 \mathrm{kbar}$ are inconsistent with nearby sillimanite localities, Pressure estimates of greater than $7 \mathrm{kbar}$ are inconsistent with an akermanite occurrence at Cascade Slide $[14,15]$ only a few kilometers from the ferrosilite ${ }_{95}$ locality. Similar inconsistencies also noted from other field areas (Nain [7], Greenland [8], and Norway [10,45]) suggest that this barometer, as it has been applied thus far, apparently yields pressures that are about one to three kilobars too high. Consequently, we have undertaken an experimental and theoretical re-evaluation of this important barometer.

\section{Experimental methods}

\subsection{Starting materials}

Starting materials were prepared from electrolytically reduced $\mathrm{Fe}$ powder and natural quartz from

\footnotetext{
* Pyroxene and olivine compositions cited in this paper refer to the ratio $\mathrm{Fe}^{2+} /\left(\mathrm{Fe}^{2+}+\mathrm{Mg}\right)$ unless otherwise specified.
}

Brazil. An equimolar mixture of $\mathrm{Fe}+$ quartz was reacted in a $\mathrm{CO}_{2} / \mathrm{H}_{2}$ gas mixing furnace at approximately $1100^{\circ} \mathrm{C}$ and $f_{\mathrm{O}_{2}} \simeq 10^{-13}$ for 3 days with grinding to approximately -200 mesh every 12 hours. The fayalite was then analyzed by optical, X-ray and electron microprobe techniques to insure that it was homogeneous and stoichiometric and did not contain any inclusions of unreacted $\mathrm{Fe}$ metal. This mixture was then reacted in a piston-cylinder device using silver capsules with $1 \mathrm{wt} . \% \mathrm{H}_{2} \mathrm{O}$ at approximately 20 kbar and $900^{\circ} \mathrm{C}(\sim 24$ hours $)$ to synthesize ferrosilite $\left(\mathrm{FeSiO}_{3}\right)$. The run product (pyroxene with traces of quartz) was also analyzed by optical, X-ray, and microprobe to insure that the pyroxene was homogeneous and stoichiometric. Small excesses of $\mathrm{SiO}_{2}$ were used in the synthesis of orthopyroxene and olivine to ensure complete reactions and to saturate the vapor phase in runs where water was used to enhance reaction rate. These two starting materials as well as $\mathrm{FeSiO}_{3}$ synthesized in a 48-hour run (at $20 \mathrm{kbar}, 900^{\circ} \mathrm{C}$ and $2 \mathrm{wt} . \% \mathrm{H}_{2} \mathrm{O}$ ) were analyzed with Mössbauer spectroscopy to check for $\mathrm{Fe}^{3+}$. Spectra were collected for approximately 72 hours, and no $\mathrm{Fe}^{3+}$ was detectable in any of the starting materials (the limit of detection was $<1 \%$ of the total Fe) (Dollase, written communication; see also following paper.)

\subsection{Capsules and run procedure}

Although the $f_{\mathrm{O}_{2}}$ in our furnace assemblies for the piston-cylinder apparatus is buffered at values near those of Ni-NiO (Hill and Boettcher, unpublished), which is somewhat above the stability of fayalite, no magnetite was found in any of the run products. Consequently, no external solid buffer was deemed necessary. For every run an equimolar amount of ferrosilite and fayalite-quartz was sealed in silver $\left(\mathrm{Ag}_{100}\right)$ capsules. For runs of $\leqslant 900^{\circ} \mathrm{C}$ approximately $1 \mathrm{wt} . \% \mathrm{H}_{2} \mathrm{O}$ was also loaded in the capsules to help promote reaction rates. Experiments above $900^{\circ} \mathrm{C}$ were run dry.

All experiments were in a piston-cylinder apparatus similar to that described by Boyd and England [16]. For all runs we used a 25.4-mm-diameter furnace assembly and piston (Boettcher, in Johannes et al. [17]). Capsules were placed horizontally in the notched top surface of a cylinder of boron nitride 
that overlay a cylinder of talc and disc of pyrophyllite. To avoid contamination of the thermocouple a strip of $\mathrm{Pt}$ foil was placed between the capsule and the thermocouple, which passed successively through cylinders of Solenhofen limestone, pyrophyllite and boron nitride in the upper part of the furnace assembly. These were surrounded by a cylindrical graphite furnace inside a cylinder of talc with a ring of fired pyrophyllite at the base of the talc cylinder. The entire assembly was surrounded by a sheet of lead foil and lubricated with a slurry of $\mathrm{MoS}_{2}$ and perfluorkerosene. Temperatures were measured by $\mathrm{Pt}-\mathrm{Pt}_{90} \mathrm{Rh}_{10}$ thermocouples. No correction for the effect of pressure on emf was applied.

For every experiment we used the piston-in method [17]. First, a pressure of roughly $10 \%$ below that to be maintained during the run was applied to the furnace assembly. The temperature was then increased to the appropriate value over a period of approximately 10 minutes. Finally, the pressure was increased to the desired value. A pressure correction of $-6 \%$ was applied. This correction was determined by comparison with the $\mathrm{LiCl}$ melting curve [18] and the albite-quartz-jadeite boundary [17] as corroborated by the hydrostatic determinations of Hays and Bell [19].

All run products were analyzed optically and by $\mathrm{X}$-ray diffraction. For most runs (see Table 1) reaction direction was immediately obvious by optical examination. For those runs where ferrosilite, fayalite and quartz were all present in significant amounts, a change in X-ray peak intensities was used to infer reaction direction. A change of X-ray peak intensities of less than $20 \%$ was taken as "no reaction". Many (approximately 15) of the run products were analyzed by electron microprobe. The fayalite and ferrosilite were analyzed on the automated ARL-EMX electron microprobe analyzer at UCLA using wavelength dispersive ADP and LiF crystals, with synthetic fayalite, magnetite, and a natural spessartine-rich garnet (to check $\mathrm{SiO}_{2}$ against fayalite) as standards. Spectrometer data were reduced using the correction procedures of Bence and Albee [20]. We checked for the presence of any other elements besides $\mathrm{Si}$ and $\mathrm{Fe}$ by analyzing run products using EDA with counting times up to 1000 seconds under conditions that would have easily allowed detection of elements $Z \geqslant$ $\mathrm{Na}$ at levels of $0.1 \mathrm{wt} . \%$, were any present. These results indicate that within the capabilities of the analytical techniques, the ferrosilite and fayalite are homogeneous and stoichiometric.

Microprobe analyses of Adirondack iron-rich orthopyroxenes (Table 2) were obtained using an ARL-EMX microprobe analyzer at the University of Michigan with wavelength dispersive LiF, PET, and TAP crystal spectrometers. Microprobe procedures identical to those used in this study are described in detail in Bohlen and Essene [21].

\section{Experimental results and discussion}

Results from the piston-cylinder experiments are listed in Table 1 and plotted in Fig. 1. The reversals locate the equilibrium boundary between ferrosilite

\section{TABLE 1}

\section{Run data}

\begin{tabular}{|c|c|c|c|c|}
\hline $\begin{array}{l}\text { Run } \\
\text { No. }\end{array}$ & $\begin{array}{l}T \\
\left({ }^{\circ} \mathrm{C}\right)\end{array}$ & $\begin{array}{l}P \\
\text { (kbar) }\end{array}$ & $\begin{array}{l}\text { Duration } \\
\text { (hours) }\end{array}$ & Products \\
\hline 46 & 700 & 10.5 & 48 & fayalite $+q t z+\mathrm{fs}$ \\
\hline 47 & 700 & 10.6 & 48 & $f s+$ fayalite + qtz \\
\hline 93 & 750 & 11.0 & 22 & $f s+($ fayalite + qtz $)$ \\
\hline 94 & 750 & 10.8 & 23 & fayalite $+q t z+(\mathrm{fs})$ \\
\hline 30 & 800 & 11.0 & 18.5 & fayalite $+q t z$ \\
\hline 31 & 800 & 11.2 & 15 & fayalite $+q t z+(\mathrm{fs})$ \\
\hline 36 & 800 & 11.4 & 22 & fayalite $+q t z+(\mathrm{fs})$ \\
\hline 38 & 800 & 11.5 & 12 & fayalite $+q t z+\mathrm{fs}$ \\
\hline 42 & 800 & 11.6 & 22 & $f s+$ fayalite + qtz \\
\hline 39 & 850 & 11.8 & 19 & fayalite $+q t z$ \\
\hline 41 & 850 & 12.0 & 23.5 & $f s+$ (fayalite $+q t z)$ \\
\hline 11 & 900 & 13.5 & 23.5 & $f_{s}$ \\
\hline 12 & 900 & 12.0 & 19 & fayalite $+q t z$ \\
\hline 13 & 900 & 12.5 & 21 & fayalite $+q t z+(\mathrm{fs})$ \\
\hline 14 & 900 & 13.0 & 23 & $f s+($ fayalite $+q t z)$ \\
\hline 15 & 900 & 12.7 & 23 & $f s+($ fayalite $+q t z)$ \\
\hline 16 & 900 & 12.6 & 24 & $f s+$ (fayalite + qtz) \\
\hline 92 & 950 & 13.3 & 19 & fayalite $+q t z$ (fs) \\
\hline 89 & 950 & 13.4 & 23 & $f s+($ fayalite $+q t z)$ \\
\hline 20 & 1000 & 14.5 & 23 & fs \\
\hline 22 & 1000 & 14.0 & 26 & fayalite $+q t z$ \\
\hline 24 & 1000 & 14.3 & 22.5 & $f s+$ fayalite $+q t z$ \\
\hline 26 & 1000 & 14.2 & 24.5 & $f s+($ fayalite $+q t z)$ \\
\hline 28 & 1000 & 14.1 & 20 & $f s+$ (fayalite + qtz) \\
\hline 27 & 1050 & 15.3 & 21 & $f s$ \\
\hline 29 & 1050 & 15.0 & 9 & $f s+($ fayalite + qtz $)$ \\
\hline 33 & 1050 & 14.8 & 16 & fayalite $+q t z(\mathrm{fs})$ \\
\hline
\end{tabular}

Italics indicate dominant phase(s).

Parentheses indicate very minor to trace amounts. 


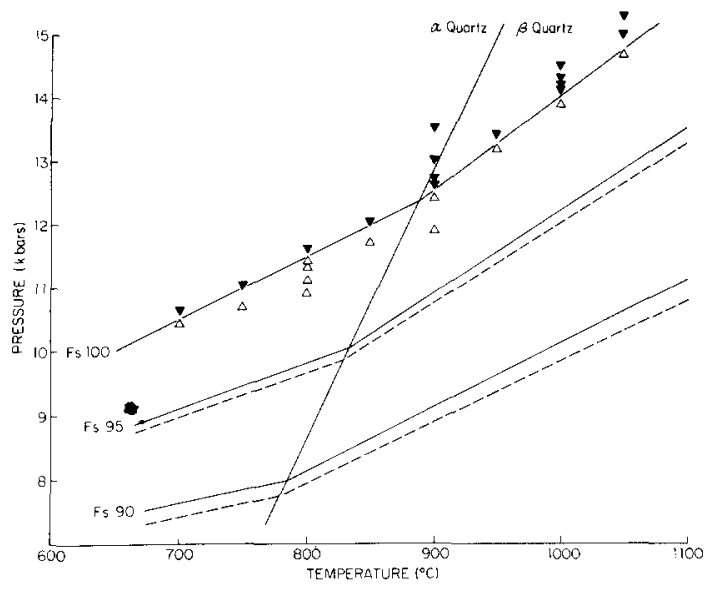

Fig. 1. Pressure-temperature projection for ferrosilite $\leftrightarrows$ fayalite + quartz. $\nabla$ indicates that ferrosilite grew from fayalite-quartz; $\triangle$ indicates that ferrosilite broke down to fayalite-quartz. The calculated effect of 5 and 10 mole $\%$ $\mathrm{MgSiO}_{3}$ on pyroxene stability is shown for $K_{D}$ defined by Fig. 3. The solid line indicates the effect using the activity data of Saxena and Ghose [33]; the dashed line indicates the effect assuming $a_{\mathrm{FeSiO}_{3}}=\left(X_{\mathrm{Fe}}\right)^{2}$.

and fayalite-quartz reproducibly to within $0.1 \mathrm{kbar}$. The boundary changes slope from $\mathrm{d} P / \mathrm{d} T=10 \mathrm{bar} /{ }^{\circ} \mathrm{C}$ to $\mathrm{d} P / \mathrm{d} T=15 \mathrm{bar} /{ }^{\circ} \mathrm{C}$ where it intersects the $\alpha-\beta$ quartz transition [22]. This change agrees precisely with that calculated from entropy and volume data [49] (assuming the change in the $\Delta S$ reaction $=\Delta S$ $\alpha-\beta$ quartz at $T, P$ of intersection of ferrosilite breakdown with $\alpha-\beta$ quartz), but only if the volumes of the solid phases are corrected for thermal expansion and compressibility. The reversals agree well with those of Smith [1] if a $-8 \%$ pressure correction is applied to his uncorrected, nominal pressures. Our uncorrected data pass through two of three of Smith's reversals. Only at $900^{\circ} \mathrm{C}$ do our uncorrected data fail to pass through his reversal, but even there the two data sets disagree by less than $0.2 \mathrm{kbar}$. In short, there is excellent agreement between the two studies considering that Smith used $12.7-\mathrm{mm}$ furnace assemblies with a modified piston-out technique and we used piston-in with 25.4-mm furnace assemblies.

\section{Effect of additional components}

Perhaps the most significant of all diluents in the $\mathrm{Fe}_{2} \mathrm{SiO}_{4}-\mathrm{SiO}_{2}$ system is $\mathrm{Mg}_{2} \mathrm{SiO}_{4}$. Previous workers have expended much effort to model or experimentally calibrate the effect of $\mathrm{Mg}^{2+}$ on orthopyroxene-olivine-quartz stability. Smith [1] experimentally investigated the effect of $\mathrm{Mg}_{2} \mathrm{SiO}_{4}$ on the system at $900^{\circ} \mathrm{C}$ and showed how small amounts of $\mathrm{MgSiO}_{3}$ in $\mathrm{FeSiO}_{3}$ dramatically extend pyroxene stability. Unfortunately Smith did not reverse the position of the three-phase olivine-quartz-pyroxene field and did not analyze his run products by microprobe. As a result, the position of the three-phase loop is not tightly constrained, and the experiments cannot be used as a solid basis from which to extrapolate the effect of $\mathrm{MgSiO}_{3}$ solution on pyroxene stability to other $P$ - $T$ - $X$ conditions. Accurate location of the three-phase loop is equivalent to experimentally reversing the $K_{D}{ }^{*}$, which is important in modeling the effect of additional components.

Successful thermodynamic modeling of $\mathrm{Fe}_{2} \mathrm{SiO}_{4}$ $\mathrm{Mg}_{2} \mathrm{SiO}_{4}$ depends on several factors, perhaps the most important of which is the need for accurate activity data. Other factors such as the change in $\Delta V_{\text {reaction }}$ with $P$ and $T$ and the change in $K_{D}^{\text {opx-oliv }}$ Mg-Fe with composition can further complicate matters. Fig. 2 shows the volume change of the reaction as a function of $P-T$. It can be seen that the $\Delta V_{\text {reaction }}$ is quite small and that changes of molar volumes as a function of $P-T$ result in changes of up to $20 \%$ in the $\Delta V_{\text {reaction }}$ in the $P-T$ range of interest. We have assumed that $\Delta V_{T}^{P}=\Delta V_{T}^{0}+\Delta V_{298^{\circ}}^{P}-\Delta V_{298}^{0}{ }^{\circ}$ (high-temperature volume data from Skinner [26], Smyth [27], Sueno et al. [28], using compressibility data from Birch [50], orthopyroxene compressibility estimated from other pyroxenes), and small errors could remain in the calculated $\Delta V_{T}^{P}$.

Fig. 3 shows Mg-Fe distribution data for coexisting $\mathrm{Fe}$-rich olivine and orthopyroxene from several field areas where the assemblages equilibrated at approximately the same temperature $\left(800 \pm 50^{\circ} \mathrm{C}\right)[7,8,29$, $30]$. The diagram shows the effect of composition on $K_{\mathrm{D}}$, an effect that was originally noted by Ramberg and DeVore [51]. Other parameters such as $P$ and $T$ apparently have little effect on $K_{D}$ within the conditions of interest $[31,32]$. The effect of composition

${ }^{*} K_{D}$, the distribution coefficient is defined as the ratio of cations in coexisting minerals. For example $K_{D \mathrm{Mg}-\mathrm{Fe}}^{\mathrm{opx}}$ is calculated: $K_{D \mathrm{Mg}-\mathrm{Fe}}^{\text {opx-oliv }}=\left[\mathrm{Mg}^{\mathrm{opx}} / \mathrm{Fe}^{\mathrm{opx}}\right]\left[\mathrm{Fe}^{\mathrm{oliv}} / \mathrm{Mg}^{\text {oliv }}\right]$. 

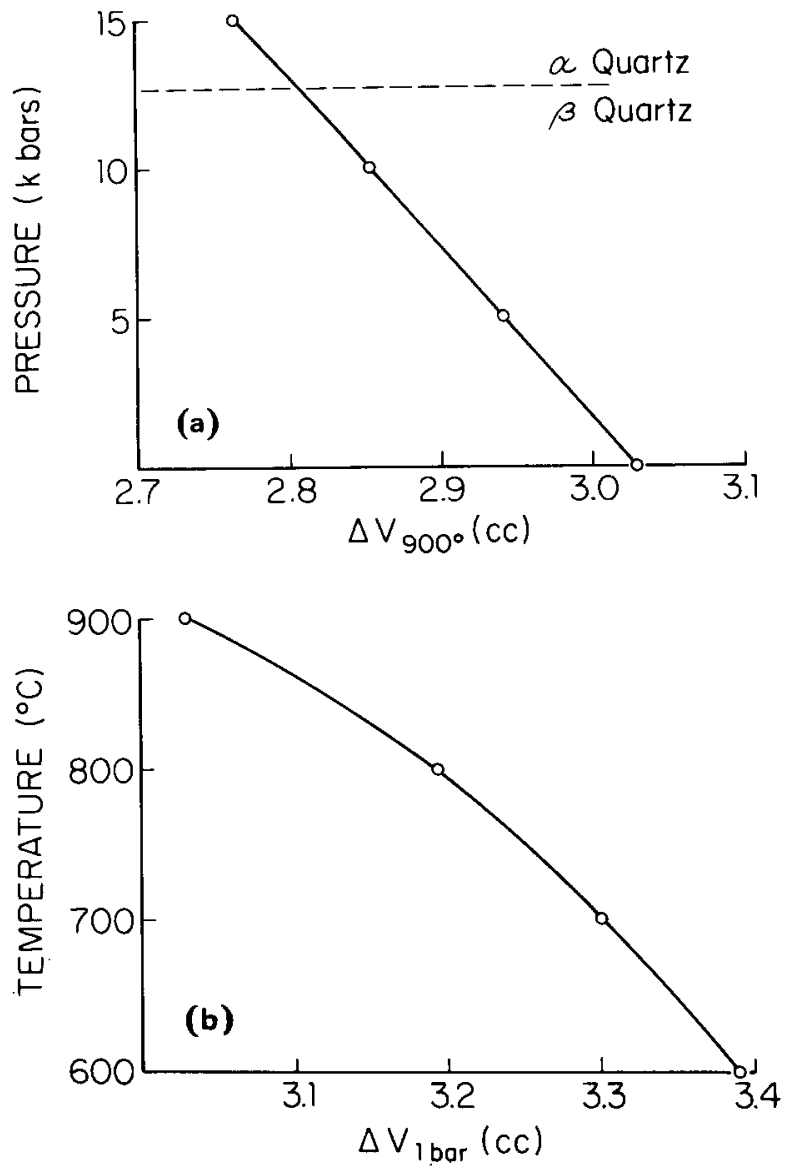

Fig. 2. (a) Plot of volume change of the reaction $2 \mathrm{FeSiO}_{3} \leftrightarrows$ $\mathrm{Fe}_{2} \mathrm{SiO}_{4}+\mathrm{SiO}_{2}$ as a function of pressure at $900^{\circ} \mathrm{C}$. Data for the $\alpha-\beta$ quartz transition from Cohen and Klement [22]. (b) Plot of volume change of the reaction as a function of temperature at 1 bar.

on $K_{D}$ and $P-T$ on $\Delta V$ are both significant and must be considered in calculations on Fe-Mg pyroxene stability.

Taking into account the dependence of $\Delta V$ on $P$ and $T$ and the dependence of $K_{D}$ on $\mathrm{Fe}^{2+} /\left(\mathrm{Fe}^{2+}+\mathrm{Mg}\right)$, we have calculated the effect of 5 and 10 mole $\%$ $\mathrm{Mg}_{2} \mathrm{Si}_{2} \mathrm{O}_{6}$ on orthopyroxene stability (Fig. 1). We have assumed an ideal ionic model $\left(a=X_{\mathrm{Fe}}^{2}\right)$ for olivine and have chosen two models for orthopyroxene activities, one based upon calculated activities, assuming a simple mixing model for pyroxene sites [33], the other an ideal ionic model $\left(a=X_{\mathrm{Fe}}^{2}\right)$. We have calculated the pressure shift using the following

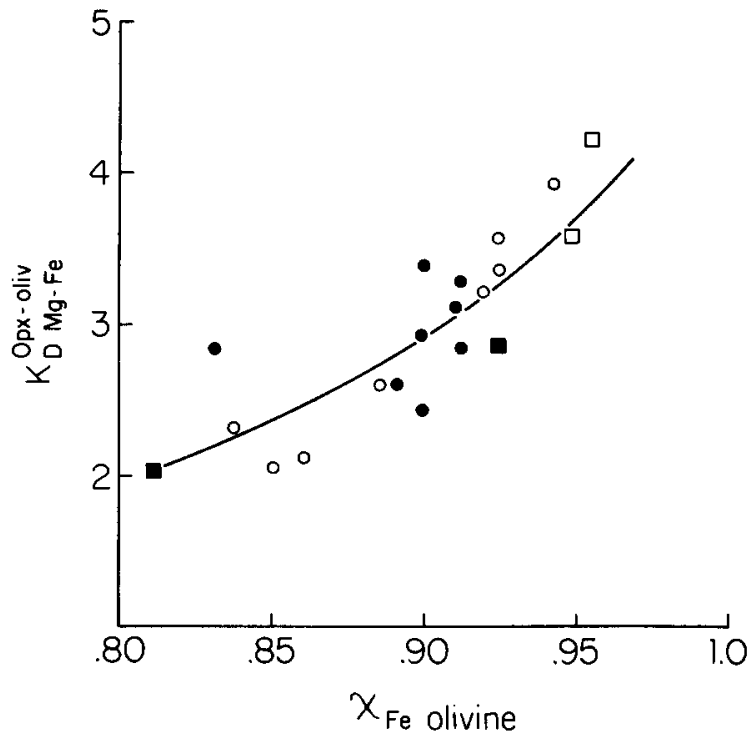

Fig. 3. Plot of $K_{D}^{\mathrm{OpX} \text {-oliv }}$ as a function of mole fraction of $\mathrm{Fe}$ in olivine for metamorphic olivine-pyroxene pairs. The symbols $\circ, \bullet, \square, \approx$ indicate data from Nain [7], Minnesota [29], Greenland [8], and Norway [30], respectively.

equation:

$\Delta P=\frac{-R T(41.84)}{\Delta V} \ln \frac{a_{\text {fayalite in olivine }}}{a_{\text {ferrosilite in op } \mathrm{x}}}$

For these diluents, the two models are very similar, and consideration of still other models, such as an ideal-molecular model yields a similar $\Delta P$ for $X_{\mathrm{Fe}} \geqslant$ 0.9 in orthopyroxene. However, the two models shown in Fig. 1 become increasingly dissimilar with larger amounts of $\mathrm{Mg}_{2} \mathrm{Si}_{2} \mathrm{O}_{6}$ solid solution. Using the Saxena and Ghose activity data [33], the slopes of the isopleths become negative for $X_{\mathrm{Fe} \text { opx }} \leqslant 0.8$ and linear extrapolation of their activity coefficients from 800 to $900^{\circ} \mathrm{C}$ yields a slight disagreement $(1-2$ mole $\% \mathrm{FeSiO}_{3}$ ) between the calculated isopleths and Smith's half-reversals. The ideal ionic model also yields similar disagreements between the calculated isopleths and experimental brackets, even though the slopes of the isopleths remain positive through $X_{\mathrm{Fe} \text { opx }}=0.7$. Very slight changes in the pyroxene activity data change the topology significantly; therefore, these models need to be tested against reversed experiments at $800-1000^{\circ} \mathrm{C}$ to allow modeling of pyroxene and olivine activities. It is important to 
note that for less than 10 mole $\% \mathrm{Mg}_{2} \mathrm{Si}_{2} \mathrm{O}_{6}$ several models yield quite similar $\Delta P$, suggesting that the calculated ispleths are approximately correct, perhaps to within $\pm 0.5 \mathrm{kbar}$.

Berg [7] and Jaffe et al. [9] have used a phase diagram showing isopleths with constant slope, parallel to the end-member equilibrium boundary. This requires a constant $\Delta P$ (from equation 1$)$ or a $\ln K$ that decreases with increasing temperature. The diagram does not take into account the effect of the $\alpha-\beta$ quartz transition, the effect of $P$ and $T$ on $\Delta V$ and the compositional dependence of $K_{D}^{\mathrm{opx}} \mathrm{Mg}$ - olive (which reduces, not increases, $\Delta P$ unless pyroxene activity coefficients are sufficiently large to counterbalance the $K_{D}$ shift), and apparently neglects uncertainties concerning pyroxene and olivine activity data. Unless there is some fortuitous counterbalancing of errors in these variables, their phase diagram cannot be correct in detail.

Even though $\mathrm{Mg}_{2} \mathrm{Si}_{2} \mathrm{O}_{6}$ may be the most important diluent in Fe-rich orthopyroxenes, other components including $\mathrm{Ca}, \mathrm{Na}, \mathrm{Al}, \mathrm{Fe}^{3+}$, $\mathrm{Ti}$ and $\mathrm{Mn}$ ty pically make up between 2-10 mole \%. To date, only the effect of $\mathrm{Mn}$ has been experimentally calibrated ([11], see following paper). Mn shows a slight preference for orthopyroxene relative to olivine and extends the stability of opx by about $0.6 \mathrm{kbar}$ for $0.05 X_{\mathrm{MnSiO}_{3}}$. Data from natural orthopyroxene-olivine-quartz assemblages indicate that $\mathrm{Ca}, \mathrm{Na}, \mathrm{Al}, \mathrm{Ti}$, and $\mathrm{Fe}^{3+}$ are all strongly partitioned into orthopyroxene, suggesting that these impurities would also extend the stability of pyroxene and that their effects may be larger than those for equivalent amounts of Mn. Unfortunately, the magnitude of the extension cannot be accurately determined because of the lack of pertinent activity data. However, an ideal model should permit calculation of an approximate extension to within $\pm 20-40 \%$ of the actual value. To emphasize the potential significance of additional components, one can take, for example, an Fe-rich orthopyroxene from the Adirondacks (Po-17, Table 2) and calculate the $\Delta P$ (from eq. 1 ) using different models for pyroxene activity. If we choose a simple model such as $a_{\mathrm{Fe}_{2} \mathrm{Si}_{2} \mathrm{O}_{6}}=\mathrm{Fe}^{2+} /\left(\mathrm{Fe}^{2+}+\mathrm{Mg}\right)$, the activity of the ferrosilite component in Po-17 is 0.95 . However, this model completely neglects the effect of other components and will yield unrealistically high pressures. Another simple model such as
TABLE 2

Microprobe analyses of Fe-rich orthopyroxenes from the Adirondacks

\begin{tabular}{|c|c|c|c|c|c|}
\hline & $X Y-6$ & IL-8 & SR-29 & SL-26 & Po-17* \\
\hline $\mathrm{SiO}_{2}$ & 46.7 & 46.2 & 45.4 & 45.7 & 45.2 \\
\hline $\mathrm{TiO}_{2}$ & 0.1 & 0.1 & 0.1 & 0.1 & 0.1 \\
\hline $\mathrm{Al}_{2} \mathrm{O}_{3}$ & 0.3 & 0.4 & 0.2 & 0.3 & 0.5 \\
\hline $\mathrm{Cr}_{2} \mathrm{O}_{3}$ & $<0.1$ & $<0.1$ & $<0.1$ & $<0.1$ & 0.1 \\
\hline $\mathrm{MgO}$ & 4.3 & 2.9 & 4.5 & 1.8 & 1.4 \\
\hline $\mathrm{ZnO}$ & $<0.1$ & $<0.1$ & $<0.1$ & $<0.1$ & 0.6 \\
\hline $\mathrm{FeO} * *$ & 46.3 & 49.8 & 47.9 & 49.4 & 50.1 \\
\hline $\mathrm{MnO}$ & 1.1 & 0.5 & 0.7 & 0.8 & 1.3 \\
\hline $\mathrm{CaO}$ & 0.7 & 0.5 & 0.8 & 0.9 & 0.8 \\
\hline $\mathrm{Na}_{2} \mathrm{O}$ & $<0.1$ & $<0.1$ & $<0.1$ & $<0.1$ & 0.1 \\
\hline $\mathrm{K}_{2} \mathrm{O}$ & $<0.1$ & $<0.1$ & $<0.1$ & $<0.1$ & $<0.1$ \\
\hline Total & $\overline{99.5}$ & $\overline{100.4}$ & $\overline{99.6}$ & $\overline{99.0}$ & $\overline{100.2}$ \\
\hline $\mathrm{Si}$ & 1.99 & 1.98 & 1.93 & 1.99 & 1.97 \\
\hline $\mathrm{Al}^{\mathrm{IV}}$ & 0.01 & 0.02 & 0.01 & 0.01 & 0.02 \\
\hline $\mathrm{Al}^{\mathrm{VI}}$ & 0.01 & 0.00 & 0.00 & 0.01 & 0.00 \\
\hline $\mathrm{Ti}$ & 0.00 & 0.00 & 0.00 & 0.00 & 0.00 \\
\hline $\mathrm{Cr}$ & 0.00 & 0.00 & 0.00 & 0.00 & 0.00 \\
\hline $\mathrm{Fe}^{3+}$ & 0.00 & 0.02 & 0.01 & 0.01 & 0.02 \\
\hline $\mathrm{Mg}$ & 0.27 & 0.18 & 0.29 & 0.12 & 0.09 \\
\hline $\mathrm{Zn}$ & 0.00 & 0.00 & 0.00 & 0.00 & 0.02 \\
\hline $\mathrm{Fe}^{2+}$ & 1.65 & 1.77 & 1.70 & 1.79 & 1.80 \\
\hline $\mathrm{Mn}$ & 0.04 & 0.01 & 0.03 & 0.03 & 0.05 \\
\hline $\mathrm{Ca}$ & 0.03 & 0.02 & 0.03 & 0.04 & 0.04 \\
\hline $\mathrm{Na}$ & 0.00 & 0.00 & 0.00 & 0.01 & 0.01 \\
\hline $\mathrm{K}$ & 0.00 & 0.00 & 0.00 & 0.00 & 0.00 \\
\hline
\end{tabular}

* Taken from Jaffe et al. [46].

** Total iron as $\mathrm{FeO} ; \mathrm{Fe}^{3+}$ calculated from stoichiometry: $\mathrm{Fe}^{3+}=\mathrm{Al}^{\mathrm{IV}}-\mathrm{Al}{ }^{\mathrm{VI}}+\mathrm{Na}+\mathrm{K}-2 \mathrm{Ti}-\mathrm{Cr}$.

$a_{\mathrm{Fe}_{2} \mathrm{Si}_{2} \mathrm{O}_{6}}=\mathrm{Fe}^{2+} / 2$ treats additonal components as inert diluents and neglects activity coefficients that might be as large as 1.1 [33]. Taking a somewhat more complicated model, a two-site ionic model of

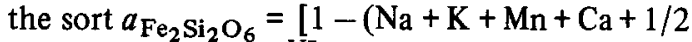
$\mathrm{Mg})] \cdot\left[1-\left(\mathrm{Ti}+\mathrm{Al}^{\mathrm{VI}}+\mathrm{Cr}+\mathrm{Zn}+1 / 2 \mathrm{Mg}\right)\right]$, one

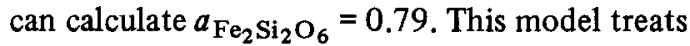
$\mathrm{Mg}-\mathrm{Fe}$ as an ideal solution, but it accounts for reduction in Fs activity by considering the blocking effect of cations ordered into the M2 and M1 sites. For $\mathrm{Al}^{\mathrm{IV}}$ one can assume a molecular model as discussed by Wood [34]; hence the activity of $\mathrm{Fe}_{2} \mathrm{Si}_{2} \mathrm{O}_{6}$ is already reduced by the dilution effect of $\mathrm{Al}$ on the $\mathrm{Ml}$ site. To calculate a $\Delta P$ from equation (1) one must 
assume a $K_{D}$, because the $\mathrm{F}_{s_{55}}$ reported by Jaffe et al. [9] does not coexist with olivine + quartz. This will yield minimum pressures necessary to stabilize the pyroxene. Based on data in Fig. 3 the $K_{D}$ will be near $3.5 \pm 0.5$. Calculations using the two activity models [(1) $\left.a_{\mathrm{Fs}}=\mathrm{Fe}^{2+} / 2 ;(2) a_{\mathrm{Fs}}=\left(X_{\mathrm{Fe}}^{\mathrm{M} 2}\right)\left(X_{\mathrm{Fe}}^{\mathrm{Mi}}\right)\right]$ yield minimum pressures of 8 and $5 \mathrm{kbar}$, respectively. These probably establish upper and lower limits to the minimum pressure because of the manner in which each model treats the diluting components. Because the $\Delta V$ of this reaction is small, even minor amounts of additional components yield estimates which err to the side of high pressures. Therefore, it is important to check results obtained from orthopyroxene-olivine-quartz barometry against pressures obtained from other methods.

\section{Application of orthopyroxene-olivine-quartz barometry - Adirondacks}

Metamorphic pressures in the Adirondacks can be characterized by pyrite-pyrrhotite-sphalerite, $\mathrm{Al}_{2} \mathrm{SiO}_{5}$ minerals, plagioclase-garnet- $\mathrm{Al}_{2} \mathrm{SiO}_{5}$-quartz, ferrosiliterich pyroxenes, fayalite-quartz and by the assemblage monticellite-wollastonite-akermanite. Because several of these barometers are temperature-dependent, equilibration temperatures must be known to within $50-75^{\circ} \mathrm{C}$ before pressures can be inferred.

Metamorphic temperatures have been determined across the Adirondacks $[12,13]$. These data were obtained using two independent thermometers, coexisting feldspars [47] and coexisting iron-titanium oxides [48], and both are in good agreement (Fig. 4). Using these temperature data, metamorphic pressures can be restricted to less than $9.8,7.8$, and $5.8 \mathrm{kbar}$ for metamorphic temperatures of less than 800,700 , and $600^{\circ} \mathrm{C}$. These were determined from sillimanitebearing paragneisses found sporadically throughout the Adirondacks, using the kyanite-sillimanite boundary of Richardson et al. [35]. With the exception of one locality, sillimanite is the only $\mathrm{Al}_{2} \mathrm{SiO}_{5}$ polymorph found in the Adirondacks. The single kyanite locality in the Blue Mountain Lake Quadrangle (Geraghty, personal communication, and Boone [36]) is itself surrounded by sillimanite localities. Assuming that the Bohlen and Essene [12,13] thermometry is correct, metamorphic pressures in the Blue Moun-

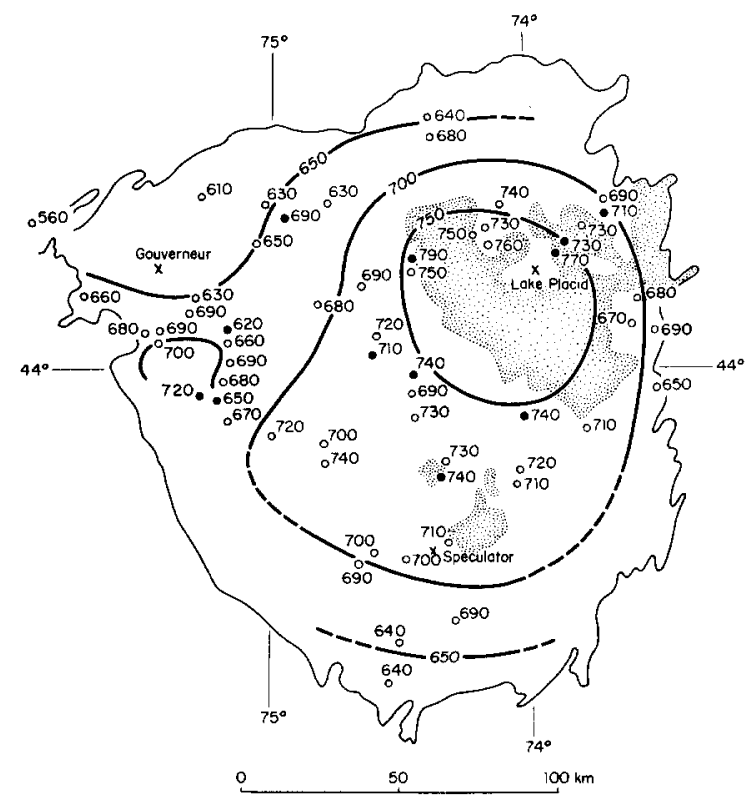

Fig. 4. Adirondack temperature data obtained by Fe-Ti oxides ( $\bullet$ ) and by two feldspars ( $(0)$ (from Bohlen and Essene [13]).

tain Lake area can be restricted to $8 \pm 0.5 \mathrm{kbar}$ based on kyanite-sillimanite equilibria of Richardson et al. [35] for $T=730 \pm 30^{\circ} \mathrm{C}$. In the Tupper Lake Quadrangle (just north of the Blue Mountain Lake Quadrangle) plagioclase-garnet-sillimanite-quartz assemblages yield pressures of $7.5 \pm 1 \mathrm{kbar}$ for metamorphic temperatures of $730 \pm 30^{\circ} \mathrm{C}$, again consistent with sillimanite in the area [37]. In the western Adirondacks near Balmat-Edwards, metamorphic pressures of $6 \pm 1 \mathrm{kbar}$ are inferred from sphalerite barometry $[38,39]$. These pressures are confirmed by numerous plagioclase-garnet-sillimanite-quartz localities within $20 \mathrm{~km}$ of Balmat yielding $6 \pm 1 \mathrm{kbar}$ for metamorphic temperatures of $630 \pm 30^{\circ} \mathrm{C}$ [37]. In the Mount Marcy Quadrangle, metamorphic $P$ - $T$ can be restricted to $7 \pm 1 \mathrm{kbar}$ and $765 \pm 30^{\circ} \mathrm{C}$ by the assemblage monticellite-wollastonite-akermanite $[14,15]$. This assemblage is extremely important as it fixes an upper pressure limit in an area where metapelitic rocks containing $\mathrm{Al}_{2} \mathrm{SiO}_{5}$ polymorphs are lacking. Based on several independent barometers and thermometers, the $\boldsymbol{P}-\boldsymbol{T}$ path of metamorphism can best be described as a line roughly parallel to the kyanite-sillimanite 
boundary very near but slightly below the kyanite stability field. Therefore, our data indicate that nowhere in the Adirondacks do the metamorphic pressures exceed $9 \mathrm{kbar}$, which has been assumed to be a maximum pressure by DeWaard [40], Essene and Valley [14], Bohlen and Essene [41,42,43], and Essene et al. [44]. However, application of the previously available experimental data on Fe-rich orthopyroxenes $[1,6]$ to ferrosilite-rich pyroxenes in the Adirondacks (Fig. 5) has yielded significantly higher pressures. Based on the occurrences of $\mathrm{Fs}_{\mathrm{S}_{5}}$ in the Mount Marcy Quadrangle (less than $5 \mathrm{~km}$ from the akermanite locality $[14,15]$, Jaffe et al. have estimated minimum metamorphic pressures to be $9-11 \mathrm{kbar}$ for metamorphic temperatures of $760-790^{\circ} \mathrm{C}$. These data imply that metamorphism in the Mount Marcy area took place in the kyanite field. However, in light of the more recent experimental data presented here and the calculated effect of additional components, the pressure estimates of Jaffe et al. can be revised down-

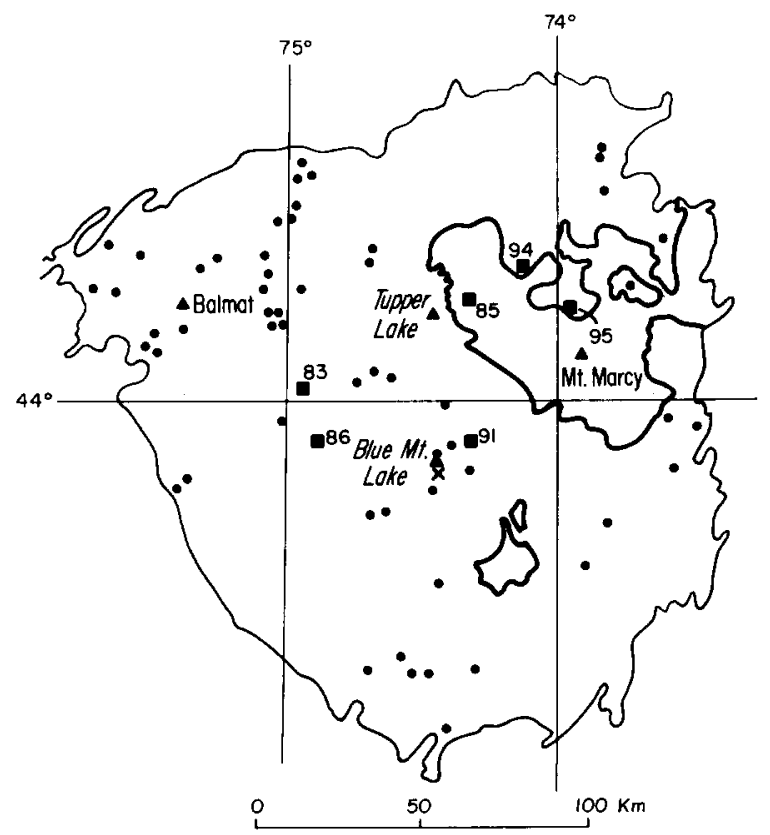

Fig. 5. Location of sillimanite $(0)$, kyanite $(X)$, and Fe-rich orthopyroxenes $\left(\mathrm{Fe}^{2+} /\left(\mathrm{Fe}^{2+}+\mathrm{Mg}\right)\right.$ ratio given) $(\omega)$ in the Adirondacks. The map outlines the Precambrian terrane of upper New York State. Anorthosites are shown in heavy outline. ward by approximately $2 \mathrm{kbar}$, placing Adirondack metamorphic pressures in the Mount Marcy area and the Adirondack Highlands in general at 7-9 kbar. Pressures of 7-9 $(8 \pm 1)$ kilobars are consonant with the widespread occurrences of sillimanite, occurrences of fayalite + quartz $\left(\mathrm{Fa}_{97}, \mathrm{Fa}_{96}\right)$ in the central and eastern Adirondacks near Wanakena and Au Sable Forks, respectively, and the occurrence of akermanite at Cascade Slide $[14,15]$, hence resolving inconsistencies that existed previously.

Reductions in estimates of metamorphic pressure for other field areas are also indicated by our data. The magnitudes of the reductions are similar to that for the Adirondacks, ranging generally between 1 and $3 \mathrm{kbar}$. In the Nain contact aureole, Berg [7] reports orthopyroxenes $\left(\mathrm{Fs}_{69-81}\right)$ that coexist with fayalitic olivine $\left(\mathrm{Fa}_{84-94}\right)$ and quartz. Berg's pressure estimates of 4-5 kbar should be reduced by 1-2 kbar based on our data. From occurrences of Fe-rich orthopyroxenes $\left(\mathrm{Fs}_{77-78} \mathrm{En}_{14-15} \mathrm{Rh}_{6} \mathrm{Wo}_{2}\right)$ coexisting with olivine $\left(\mathrm{Fa}_{89-90} \mathrm{Te}_{5-6} \mathrm{FO}_{4-5}\right)$ and quartz, Frisch and Bridgwater [8] inferred metamorphic pressures of 4-5.4 kbar for metamorphic temperatures of $750-900^{\circ} \mathrm{C}$ in iron-rich intrusions near Julianehaab, Greenland. They noted that their pressures might be high because of the effects of additional components and attempted to calculate the magnitude of these effects. We suggest a $1-2$ kbar reduction of the pressures. However, it must be noted that because of the difficulty in modeling additional components, pressures inferred from orthopyroxene-olivine-quartz assemblages containing large amounts of impurities (as noted above) will be significantly less certain than those inferred from mineral compositions requiring minimal extrapolations of the present data. Hence, until the necessary experimental work and/or more highly refined pyroxene activity data are available, the orthopyroxene-olivine-quartz geobarometer should be applied with great caution and checked against other barometers where possible.

\section{Acknowledgements}

The writers are grateful for and acknowledge the support of the Geochemistry Section of the National Science Foundation, NSF grants EAR76-22330 and 
EAR78-16413 to A.L.B., EAR75-22388 and EAR7823568 to E.J.E., Geological Society of America Penrose grant No. 2168-77 and the University of Michigan, Turner Fund grants to S.R.B. The writers would like to thank Dr. Wayne Dollase of the Department of Earth and Space Sciences, UCLA, for obtaining Mössbauer data on run materials. The writers are also indebted to Dr. Jack C. Allen (Department of Geology and Geography, Bucknell University), Wilbur C. Bigelow and Lawrence F. Allard (Department of Metallurgy and Materials Science, University of Michigan) and Dr. Wayne Dollase and Robert Jones (Department of Earth and Space Sciences, UCLA) who gave important assistance in several aspects of this research. Derwin Bell drafted the line drawings.

\section{References}

1 D. Smith, Stability of the assemblage iron-rich orthopyroxene-olivine-quartz, Am. J. Sci. 271 (1971) 370.

2 N.L. Bowen and J.F. Schairer, The system MgO-FeO$\mathrm{SiO}_{2}$, Am. J. Sci. 29 (1935) 151.

3 S. Akimoto, H. Fujisawa and T. Katsura, Synthesis of $\mathrm{FeSiO}_{3}$ pyroxene (ferrosilite) at high pressures, Jpn Acad. Proc. 40 (1964) 272.

4 D.H. Lindsley, B.T.C. Davis and I.D. MacGregor, Ferrosilite $\left(\mathrm{FeSiO}_{3}\right)$ synthesis at high pressures and temperatures, Science 144 (1964) 73.

5 D.H. Lind sley, Ferrosilite, Carnegie Inst. Washington Yearb. 64 (1965) 148.

6 B.J. Wood and R.G.J. Strens, The orthopyroxene geobarometer, Earth Planet. Sci. Lett. 11 (1971) 1.

7 J.H. Berg, Regional geobarometry in the contact aureoles of the anorthositic Nain Complex, Labrador, J. Petrol. 18 (1977) 399.

8 T. Frisch and D. Bridgwater, Iron- and manganese-rich minor intrusions emplaced under late-orogenic conditions in the Proterozoic of South Greenland, Contrib. Mineral Petrol. 57 (1976) 25.

9 H.W. Jaffe, P. Robinson and R.J. Tracy, Or thoferrosilite and other iron-rich pyroxenes in microperthite gneiss of the Mt. Marcy area, Adirondack Mountains, Am. Mineral. 63 (1978) 1116.

10 E.J. Krogh, Origin and metamorphism of iron formations and associated rocks, Lofoten-Vesteralen, N. Norway, I. The Vestpolltind Fe-Mn deposit, Lithos 10 (1977) 243.

11 S.R. Bohlen and A.L. Boettcher, The effect of manganese on orthopyroxene-olivine-quartz stability: orthopyroxene geobarometry, Geol. Soc. Am. Abstr. Progr. 10 (1978) 369 (abstract).

12 S.R. Bohlen and E.J. Essene, Feldspar and oxide thermometry of granulites in the Adirondack Highlands, Contrib. Mineral. Petrol. 62 (1977) 153.
13 S.R. Bohlen, E.J. Essene and K.S. Hoffman, Feldspar and oxide thermometry in the Adirondacks: an update, Bull. Geol. Soc. Am. (in press).

14 E.J. Essene and J.W. Valley, High pressure akermanite in the Adirondacks, Geol. Soc. Am. Abstr. Progr. 11 (1979) 11 (abstract).

15 J.W. Valley and E.J. Essene, High pressure akermanite from Cascade Slide, Adirondack Mountains, New York. Contrib. Mineral. Petrol. (in press).

16 F.R. Boyd and J.L. England, Apparatus for phase-equilibrium measurements at pressures up to 50 kilobars and temperatures up to $1750^{\circ} \mathrm{C}, \mathrm{J}$. Geophys. Res. 65 (1960) 741.

17 W. Johannes, P.M. Bell, H.K. Mao, A.L. Boettcher, D.W. Chipman, J.F. Hays, R.C. Newton and F. Seifert, An interlaboratory comparison of piston-cylinder pressure calibration using the albite-break-down reaction, Contrib. Mineral. Petrol. 32 (1971) 24.

18 S.P. Clark, Effect of pressure on the melting points of eight alkali halides, J. Chem. Phys. 31 (1959) 1526.

19 J.F. Hayes and P.M. Bell, Albite-jadeite-quartz equilibrium: a hydrostatic determination, Trans. Am. Geophys. Union 54 (1973) 482 (abstract).

20 A.E. Bence and A.L. Albee, Empirical correction factors for the electron microanalysis of silicates and oxides, $\mathrm{J}$. Geol. 76 (1968) 382.

21 S.R. Bohlen and E.J. Essene, Igneous pyroxenes from metamorphosed anorthosite massifs, Contrib. Mineral. Petrol. 65 (1978) 433.

22 L.H. Cohen and W. Klement, Jr., High-low quartz inversion: determination to 35 kilobars, J. Geophys. Res. 72 (1967) 4245.

23 T.H. Green, A.E. Ringwood and A. Major, Friction effects and pressure calibration in a piston-cylinder apparatus at high pressure and temperature, J. Geophys. Res. 71 (1966) 3589.

$24 \mathrm{~W}$. Johannes, Pressure comparing experiments with $\mathrm{NaCl}$, $\mathrm{AgCl}$, talc, and pyrophyllite assemblies in a pistoncylinder apparatus, Neues Jahrb. Mineral. Monatsh. (1978) 84.

25 J.M. Edmond and M.S. Paterson, Strength of solid pressure media and implications for high pressure apparatus, Contrib. Mineral Petrol. 30 (1971) 141.

26 B.J. Skinner, Thermal expansion, in: Handbook of Physical Constants, S.P. Clark, Jr., ed., Geol. Soc. Am. Mem. 97 (1966) 75

27 J.R. Smyth, High temperature crystal chemistry of fayalite, Am. Mineral. 60 (1975) 1092.

28 S. Sueno, M. Cameron and C.T. Prewitt, Orthoferrosilite: high temperature crystal chemistry, Am. Mineral 61 (1976) 38.

29 B. Bonnichsen, Metamorphic pyroxenes and amphibolites in the Biwabik Iron Formation, Dunka River area, Minnesota, Mineral. Soc. Am. Spec. Paper 2 (1969) 217.

30 J.C. Duchesne, Pyroxènes et olivines dans le massif de Bjerkrem-Sogndal (Norvège-méridionale). Contribution à l'étude de la série anorthosite-mangérite, 24th Int. Geol. Congr. (1972) 320. 
31 L.G. Medaris, Jr., Partitioning of $\mathrm{Fe}^{++}$and $\mathrm{Mg}^{++}$between coexisting synthetic olivine and orthopyroxene, Am. J. Sci. 267 (1969) 945.

32 Y. Matsui and O. Nishizawa, Iron (II)-magnesium exchange equilibrium between olivine and calcium free pyroxene over a temperature range $800^{\circ} \mathrm{C}$ to $1300^{\circ} \mathrm{C}$, Bull. Soc. Fr. Mineral. Cristallogr. 97 (1974) 122.

33 S.K. Saxena and S. Ghose, $\mathrm{Mg}^{2+}-\mathrm{Fe}^{2+}$ order-disorder and the thermodynamics of the orthopyroxene crystalline solution, Am. Mineral. 56 (1971) 532.

34 B.J. Wood, The solubility of alumina in orthopyroxene coexisting with garnet, Contrib. Mineral. Petrol. 46 (1974) 1.

35 S.W. Richardson, P.M. Bell and M.C. Gilbert, Kyanitesillimanite equilibrium between $700^{\circ} \mathrm{C}$ and $1500^{\circ} \mathrm{C}, \mathrm{Am}$. J. Sci. 266 (1968) 513.

36 G.M. Boone, Kyanite in Adirondack Highlands sillimanite rich gneiss, and P-T estimates of metamorphism, Geol. Soc. Am. Abstr. Progr. 10 (1978) 34 (abstract).

37 D. Perkins, III and E.J. Essene, A model for grossular activity in garnet solutions and applications to natural assemblages, Trans. Am. Geophys. Union 58 (1977) 523 (abstract).

38 D.B. DeWitt and E.J. Essene, Sphalerite geobarometry applied to Grenville marbles, Geol. Soc. Am. Abstr. Progr. 6 (1974) 709 (abstract).

39 P.E. Brown, E.J. Essene and W.C. Kelly, Sphalerite geobarometry in the Balmat-Edwards district, New York, Am. Mineral. 63 (1978) 250.

40 D. DeWaard, Facies series and $P-T$ conditions of metamorphism in the Adirondack Mountains, Proc. Kon. Ned. Akad. Wetensch., Ser. B 72 (1969) 124.

41 S.R. Bohlen and E.J. Essene, Garnet granulites of the
Adirondacks, Int. Conf. Geotherm. Geobarom. Penn State Univ. (1975) (abstract).

42 S.R. Bohlen and E.J. Essene, Garnet granulites of the Adirondacks, Geol. Soc. Am. Abstr. Progr. 8 (1976) 785 (abstract)

43 S.R. Bohlen and E.J. Essene, Errors in applying opx-olivquartz barometry, Trans. Am. Geophys. Union 58 (1977b) 1242 (abstract).

44 E.J. Essene, S.R. Bohlen and J.W. Valley, Regional metamorphism in the Adirondacks, Geol. Soc. Am. Abstr. Progr. 9 (1977) 261 (abstract).

45 D.E. Ormassen, Petrology of the Hopen mangerite-charnockite intrusion, Lofoten, north Norway, Lithos 10 (1977) 291.

46 H.W. Jaffe, P. Robinson and R.J. Tracy, Orientation of pigeonite exsolution lamellae in metamorphic augite: correlation with composition and calculated optimal phase boundaries, Am. Mineral. 60 (1975) 9.

47 A.F. Buddington and D.H. Lindsley, Iron-titanium oxide minerals and their synthetic equivalent, J. Petrol. 5 (1964) 310.

48 J.C. Stormer, Jr., A practical two-feldspar thermometer, Am. Mineral. 60 (1975) 667.

49 R.A. Robie, B.S. Hemingway and J.R. Fisher, Thermodynamic properties of minerals and related substances at $298.15 \mathrm{~K}$ and 1 bar ( $10^{5}$ pascals) pressure and at higher temperatures, U.S. Geol. Surv. Bull. 1452 (1978) 456.

50 F. Birch, Compressibility; Elastic constants, in: Handbook of Physical Constants, S.P. Clark, Jr., ed., Geol. Soc. Am. Mem. 97 (1966) 97.

$51 \mathrm{H}$. Ramberg and G. DeVore, The distribution of $\mathrm{Fe}^{++}$and $\mathrm{Mg}^{++}$in coexisting olivine and orthopyroxenes, J. Geol. 59 (1951) 193. 